\title{
OLIG2 wt Allele
}

National Cancer Institute

\section{Source}

National Cancer Institute. OLIG2 wt Allele. NCI Thesaurus. Code C68576.

Human OLIG2 wild-type allele is located in the vicinity of 21 q22.11 and is approximately 3 $\mathrm{kb}$ in length. This allele, which encodes olig odendrocyte transcription factor 2 protein, is involved in neuronal progenitor cell fate determination. The wild-type allele is expressed in oligodendrog lial tumors and is involved in a chromosomal translocation t(14;21) (q11.2;q22), which is associated with T-cell acute lymphoblastic leukemia. 